\title{
Prokaryotic carbon utilization in the dark ocean: growth efficiency, leucine-to-carbon conversion factors, and their relation
}

\author{
Federico Baltar ${ }^{1, *}$, Javier Arístegui ${ }^{1}$, Josep M. Gasol ${ }^{2}$, Gerhard J. Herndl ${ }^{3,4}$ \\ ${ }^{1}$ Facultad de Ciencias del Mar, Universidad de Las Palmas de Gran Canaria, Campus Universitario de Tafira, \\ 35017 Las Palmas de Gran Canaria, Spain \\ ${ }^{2}$ Departament de Biologia Marina i Oceanografia, Institut de Ciències del Mar-CSIC, \\ Pg. Marítim de la Barceloneta 37-49, 08003 Barcelona, Spain \\ ${ }^{3}$ Department of Marine Biology, Faculty Center of Ecology, University of Vienna, Althanstr. 14, 1090 Vienna, Austria \\ ${ }^{4}$ Department of Biological Oceanography, Royal Netherlands Institute for Sea Research, 1790 AB Den Burg, The Netherlands
}

\begin{abstract}
Experiments were conducted in the mesopelagic subtropical northeast Atlantic Ocean to determine the range of variability in the prokaryotic leucine-to-carbon conversion factor (CF), and prokaryotic growth efficiency (PGE). The way prokaryotic heterotrophic production (PHP) is calculated directly influences PGE (variations of PGE between 1 and $31 \%$ were found for a single sample). The empirically obtained deep-water CFs showed a 7 -fold variability (0.13 to $0.85 \mathrm{~kg} \mathrm{C} \mathrm{mol}^{-1} \mathrm{Leu}$ ), but were always lower than the theoretical CF of $1.55 \mathrm{~kg} \mathrm{C} \mathrm{mol}^{-1}$ Leu assuming no isotope dilution. Empirically determined CFs were highly correlated to PGE, suggesting that both parameters are representations of the same basic metabolic processes. Overall, the PGEs obtained in this study suggest that mesopelagic prokaryotic assemblages can sometimes be as important in carbon processing as their epipelagic counterparts.
\end{abstract}

KEY WORDS: Prokaryotic growth efficiency $\cdot$ Leucine-to-carbon conversion factor $\cdot$ Deep ocean

\section{INTRODUCTION}

A key concept in the study of ecosystem ecology is the balance between catabolic and anabolic processes, usually defined as the growth efficiency. This parameter quantifies the proportion of the organic carbon incorporated into biomass (production) compared to the total organic carbon uptake (production plus respiration). In the oceanic ecosystem, prokaryotes play a major role in the organic carbon fluxes, being responsible for up to $>90 \%$ of the community respiration (Robinson \& Williams 2005). Prokaryotes are also a key component of the microbial loop, acting as a trophic link (transforming dissolved into particulate organic carbon) for higher trophic levels (Azam et al. 1983). Therefore, the organic carbon concentration that will be respired $\left(\mathrm{CO}_{2}\right.$ release $)$ in the ocean and/or the amount of organic carbon that will flow through prokaryotes to higher trophic levels greatly depends on the prokaryotic growth efficiency (PGE) (Carlson et al. 2007).

Although estimating PGE in the ocean is essential, obtaining the metabolic rates involved in that assessment is not simple. Prokaryotic heterotrophic production (PHP) is frequently determined by measuring leucine or thymidine incorporation and applying an empirically obtained conversion factor to convert the leucine or thymidine incorporation rates into carbon production (del Giorgio \& Cole 1998). However, the relation between substrate incorporation and carbon produced is not constant (Ducklow 2000). This leucine (or thymidine) to carbon conversion factor (LeuCF) may vary by a factor of 10 within individual systems (e.g. Sherry et al. 2002, Alonso-Saéz et al. 2007). 
Therefore, it is generally recommended to empirically determine LeuCFs to better constrain carbon fluxes (Pulido-Villena \& Reche 2003).

To fully understand the biogeochemical carbon cycle in the ocean, it is imperative to take into account the entire depth range where metabolic processes are present. Dark ocean (>200 m depth) prokaryotes have been reported to account for ca. $75 \%$ of biomass, $50 \%$ of production (Arístegui et al. 2009), and $15 \%$ of respiration (del Giorgio \& Williams 2005) in the global ocean, thus playing a major role in the global carbon cycle. However, there are only a few studies reporting dark-ocean PGE and LeuCFs, and almost none of the available deep-ocean PGE measurements were directly estimated (but see Arístegui et al. 2005, Reinthaler et al. 2006). Recently, from a global data set of PHP and prokaryotic respiration (PR), Arístegui et al. (2009) suggested that PGE should decrease with depth to a value of ca. $4 \%$ in the bathypelagic realm assuming an epipelagic PGE of $15 \%$ (del Giorgio $\&$ Cole 2000). This decrease in PGE with depth has been associated with the decrease in substrate quality and quantity with depth (Baltar et al. 2009).

We review here existing information on deep ocean PGE and LeuCFs and report results from 13 experiments conducted to determine PGE in the mesopelagic zone of the subtropical NE Atlantic. The aim is to provide additional estimates of PGE for the dark ocean and to examine how the LeuCF estimates affect the PGE. We hypothesized that, as shown for other organic carbonlimited systems (e.g. the oligotrophic epipelagic subtropical NE Atlantic, AlonsoSaéz et al. 2007), the deep ocean conversion factors (CFs) are lower than the theoretical $\mathrm{CF}$.

\section{MATERIALS AND METHODS}

Study site and sampling. To analyze the variability of deep ocean LeuCF, 8 stations were occupied in the subtropical north Atlantic between the Canary and the Cape Verde archipelagos during the RODA-II cruise (February 2007) on board RV 'Hespérides' (Fig. 1). Samples were obtained from 4 different sites: within a cyclonic eddy (Stn R2) generated by the presence of the islands from near-shore waters (next to the
Canary Islands), in close proximity to the Cape Blanc upwelling, and from the open subtropical Atlantic Ocean. All samples were obtained from the mesopelagic realm (ranging from 350 to $1000 \mathrm{~m}$ depth) (Table 1). The samples were immediately taken to temperature-controlled chambers set at in situ temperature $\left( \pm 0.2^{\circ} \mathrm{C}\right)$.

PR and PGE. PR was measured by following the changes in dissolved oxygen concentrations during

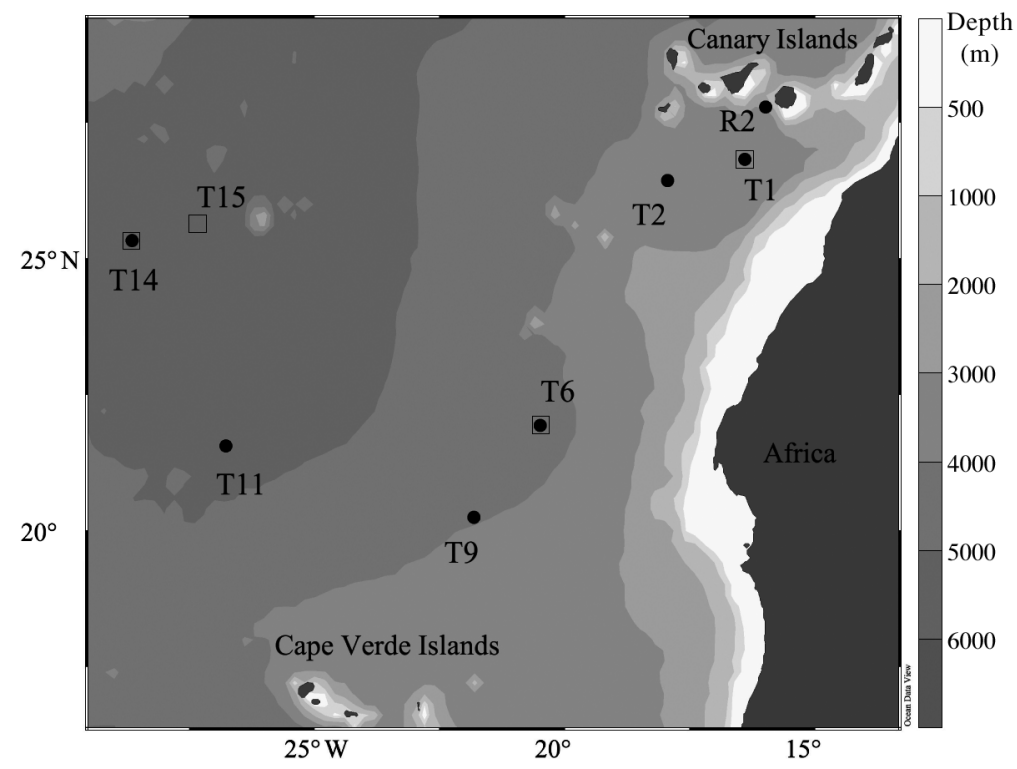

Fig. 1. Sampling stations during the RODA II cruises in February 2007. - : stations where experiments to determine prokaryotic growth efficiencies were performed. $\square$ : stations where assays to determine leucine-to-total carbon conversion factors were performed

Table 1. Temperature $\left(\mathrm{T}_{i}{ }^{\circ} \mathrm{C}\right)$, salinity, type of experiment performed, total incubation time $(\mathrm{h})$, initial prokaryotic abundance $\left(\mathrm{PA}_{i} 10^{5} \mathrm{cell} \mathrm{ml} \mathrm{m}^{-1}\right)$, initial prokaryotic heterotrophic production (PHP; pmol leu $\mathrm{l}^{-1} \mathrm{~h}^{-1}$ ), turnover time $\left(\mathrm{Tt}_{i} \mathrm{~d}\right)$, and high nucleic acid content cells (HNA; \%) in the ambient water $($ depth; $)$ collected at each station. PGE: prokaryotic growth efficiency; $\mathrm{CF}$ : conversion factor

\begin{tabular}{|c|c|c|c|c|c|c|c|c|c|}
\hline Stn & Depth & $\mathrm{T}$ & Salinity & Expt type & $\begin{array}{c}\text { Incubation } \\
\text { time (PGE/CF) }\end{array}$ & PA & PHP & $\mathrm{Tt}$ & HNA \\
\hline R2 & 350 & 14.2 & 35.995 & PGE & 48 & 4.4 & 0.17 & 424 & 21 \\
\hline R2 & 1000 & 7.8 & 35.269 & PGE & 48 & 4.3 & 0.04 & 1346 & 25 \\
\hline T1 & 540 & 10.9 & 35.473 & PGE/CF & $48 / 218$ & 0.9 & 0.13 & 112 & 36 \\
\hline $\mathrm{T} 1$ & 800 & 8.0 & 35.223 & $\mathrm{PGE} / \mathrm{CF}$ & $48 / 218$ & 0.7 & 0.11 & 107 & 33 \\
\hline T2 & 400 & 13.2 & 35.831 & PGE & 48 & 1 & 0.46 & 35 & 35 \\
\hline $\mathrm{T} 2$ & 800 & 8.7 & 35.305 & PGE & 48 & 0.6 & 0.14 & 71 & 32 \\
\hline T6 & 400 & 12.8 & 35.670 & $\mathrm{CF}$ & $-/ 190$ & 1.8 & 0.33 & 88 & 39 \\
\hline T6 & 800 & 7.8 & 35.130 & PGE/CF & 48/190 & 0.9 & 0.03 & 418 & 35 \\
\hline T9 & 400 & 11.7 & 35.498 & PGE & 48 & 1 & 0.35 & 46 & 43 \\
\hline T9 & 800 & 7.3 & 34.989 & PGE & 48 & 0.6 & 0.21 & 47 & 41 \\
\hline T11 & 400 & 12.9 & 35.681 & PGE & 48 & 1 & 0.48 & 34 & 43 \\
\hline T11 & 800 & 7.3 & 35.016 & PGE & 48 & 0.6 & 0.36 & 27 & 41 \\
\hline T14 & 400 & 14.1 & 35.920 & PGE/CF & 48/141 & 0.8 & 0.09 & 147 & 42 \\
\hline T14 & 800 & 8.5 & 35.264 & PGE/CF & 48/141 & 0.4 & 0.35 & 37 & 39 \\
\hline T15 & 400 & 13.8 & 35.889 & $\mathrm{CF}$ & $-/ 140$ & 0.8 & 0.32 & 41 & 42 \\
\hline T15 & 800 & 8.6 & 35.296 & $\mathrm{CF}$ & $-/ 140$ & 0.5 & 0.21 & 38 & 37 \\
\hline
\end{tabular}


dark incubations. Water samples drawn into carboys were carefully siphoned into 12 biological oxygen demand (BOD) bottles, and 3 replicate bottles were immediately fixed with Winkler reagents to determine the initial oxygen concentration. Three replicate bottles were incubated in the dark at in situ temperature and fixed with Winkler reagents after 24 and $48 \mathrm{~h}$. At each time step, one additional replicate bottle was used to determine prokaryotic abundance (PA) and PHP as described in 'PA and PHP'. Dissolved oxygen measurements were made by automated Winkler titrations on the basis of colorimetric end-point detection as described in Arístegui et al. (2005). PR was estimated from the difference in oxygen concentration at the start and the end of the incubation. To convert oxygen consumption to carbon respiration, a respiratory quotient of 1 was assumed (del Giorgio et al. 2006).

PGE was calculated as $(\mathrm{PHP} / \mathrm{PHP}+\mathrm{PR}) \times 100$. PR was estimated as described above in the $48 \mathrm{~h}$ incubations (see Fig. 2 for an example). PHP was estimated in 4 different ways, based on: (1) Leu incorporation at the start of the incubation using the theoretical conversion factor (1.5 $\mathrm{kg} \mathrm{C} \mathrm{mol}^{-1}$ Leu that assumes no isotope dilution); (2) the integrated PHP over the $48 \mathrm{~h}$ incubation using the theoretical conversion factor $\left(1.5 \mathrm{~kg} \mathrm{C} \mathrm{mol}^{-1}\right.$ Leu); (3) the change in prokaryotic biomass, estimated from the increase in cell numbers during the incubation and using a conservative factor of $12 \mathrm{fg} \mathrm{C} \mathrm{cell} \mathrm{f}^{-1}$ (Fukuda et al. 1998); and (4) the integrated PHP over the $48 \mathrm{~h}$ incubation using the empirically determined conversion factor of each sample in which it was determined.

PA and PHP. Picoplankton cells were enumerated using flow cytometry on a FACSCalibur (Becton Dickinson) with a laser emitting at $488 \mathrm{~nm}$ wavelength. Samples $(1.5 \mathrm{ml})$ were fixed with paraformaldehyde (1\% final concentration), incubated at $4^{\circ} \mathrm{C}$ for 15 to $30 \mathrm{~min}$, and then stored frozen in liquid nitrogen until analysis. Prior to counting the cells, $200 \mu \mathrm{l}$ of sample were stained with a DMSO-diluted SYTO-13 (Molecular Probes) stock (10:1) at $2.5 \mu \mathrm{M}$ final final concentration. Prokaryotes were identified by their signature in a plot of side scatter (SSC) versus green fluorescence (FL1).

PHP was estimated by the incorporation of tritiated leucine (specific activity $171 \mathrm{Ci} \mathrm{mmol}^{-1}$; Amersham) using the centrifugation method (Smith \& Azam 1992). Four replicates and 2 TCA-killed blanks were incubated with $40 \mathrm{nmol} \mathrm{l}^{-1}$ of ${ }^{3} \mathrm{H}$-Leu for 3 to $7 \mathrm{~h}$. Precipitation was done with ice-cold trichloroacetic acid (TCA). Although the use of $40 \mathrm{nmol}^{-1}$ as a saturating concentration was justified by concentration kinetics done on board, the ambient leucine could have diluted the tracer by 10 to $20 \%$, introducing some variability in the data.
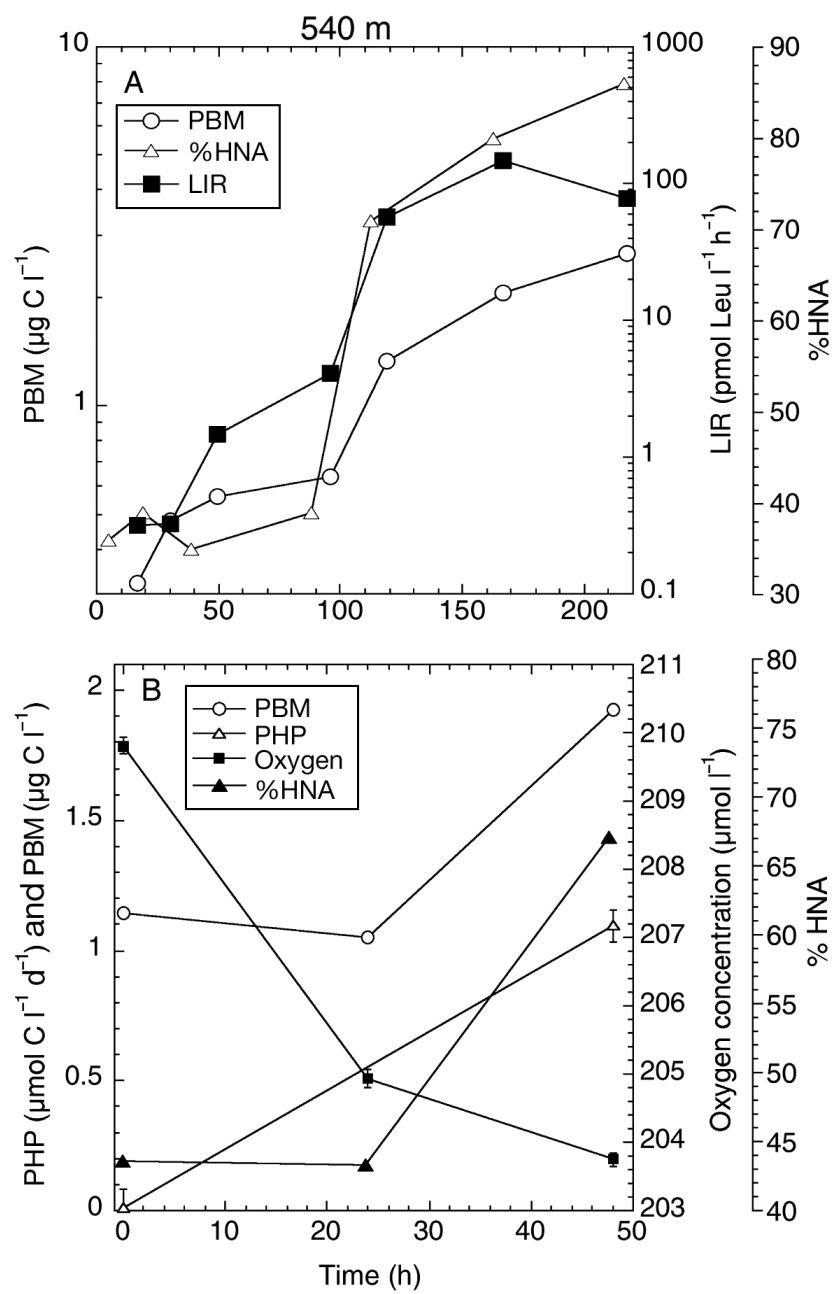

Fig. 2. (A) Mean $( \pm \mathrm{SD})$ of prokaryotic biomass $\left(\mathrm{PBM}_{i} \mu \mathrm{g} \mathrm{Cl}^{-1}\right)$, high nucleic acid content cells (HNA; \%) and leucine incorporation (LIR; pmol leu $\mathrm{l}^{-1} \mathrm{~h}^{-1}$ ) during the carbon-to-leucine conversion factor experiment at Stn T1 $(540 \mathrm{~m})$. (B) Variation in

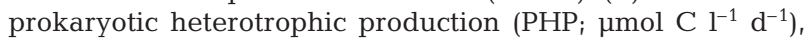
biomass ( $\left.\mathrm{PBM}_{i} \mu \mathrm{g} \mathrm{Cl}^{-1}\right)$, high nucleic acid content cells (HNA;

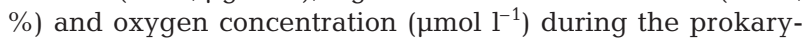
otic growth efficiency experiment at Stn T1 $(540 \mathrm{~m})$. In most of the parameters plotted, SDs are not visible since they are smaller than the symbols

Determination of LeuCF. Eight experiments were performed to determine LeuCFs for deep-water heterotrophic prokaryotic communities (see Fig.2 for an example). Each water sample was gently filtered through a $0.6 \mu \mathrm{m}$ polycarbonate filter (Millipore, GTTP), and incubated in 21 acid-clean polycarbonate bottles in the dark at in situ temperatures. Subsamples were taken for PHP and PA measurements every 12 to $24 \mathrm{~h}$ until prokaryotes reached the stationary growth phase (on average 8 measurements per experiment). CFs were calculated with the cumulative method (Bjørnsen \& Kuparinen 1991), which maximizes the use of available data. 
Statistical analyses. Data were log transformed, and normality was checked with a Shapiro-Wilks test before Pearson correlations were calculated using the freely available R software (Ihaka \& Gentleman 1996).

\section{RESULTS AND DISCUSSION}

\section{Deep-ocean variability in LeuCF}

We empirically estimated the CFs in the different stations and obtained a 7 -fold variation $(0.13$ to $0.85 \mathrm{~kg}$ $\mathrm{C} \mathrm{mol}^{-1} \mathrm{Leu}$ ) (Table 2, Fig. 2). The empirically obtained CFs were consistently lower than the theoretical CF for open ocean surface waters $\left(1.55 \mathrm{~kg} \mathrm{C} \mathrm{mol}{ }^{-1}\right.$ Leu assuming no isotope dilution; e.g. Ducklow et al. 1999, Carlson \& Ducklow 1996, Zubkov et al. 2000). Our results are in agreement with the range of $\mathrm{CFs}$ (0.02 to $1.29 \mathrm{~kg} \mathrm{C} \mathrm{mol}^{-1} \mathrm{Leu}$, mean $\left.=0.32 \mathrm{~kg} \mathrm{C} \mathrm{mol}^{-1} \mathrm{Leu}\right)$ reported by Alonso-Sáez et al. (2007) for the oligotrophic surface waters of the NE Atlantic Ocean. Furthermore, in the only other study where deep-ocean (>200 m depth) CFs are reported (Gasol et al. 2009), $\mathrm{CF}$ ranged between 0.39 and $2.38 \mathrm{~kg} \mathrm{C} \mathrm{mol}^{-1} \mathrm{Leu}$, and the latter value was the only one higher than the theoretical $\mathrm{CF}$ out of 5 measurements with no significant difference between epi- and mesopelagic CFs. Our average $\mathrm{CF}\left(0.5 \pm 0.2 \mathrm{~kg} \mathrm{C} \mathrm{mol}^{-1} \mathrm{Leu}\right)$ is similar to the mean CF of $0.4 \pm 0.2 \mathrm{~kg} \mathrm{C} \mathrm{mol}^{-1}$ Leu reported by Gasol et al. (2009) and the mean CF of $0.3 \pm 0.3 \mathrm{~kg} \mathrm{C} \mathrm{mol}^{-1}$ Leu obtained by Alonso-Sáez et al. (2007). Although it is known that CFs can substantially deviate from the theoretical CF (Kirchman 1992), the underlying reason for this is still unclear.

Alonso-Sáez et al. (2007) analyzed the cause for these lower-than-theoretical CFs in oligotrophic surface waters of the NE Atlantic by measuring the respiration and assimilation of ${ }^{14} \mathrm{C}$-labeled leucine along a productivity gradient. These authors found an increasing fraction of leucine respired and decreasing CFs

Table 2. Empirically obtained leucine-to-carbon prokaryotic conversion factors (LeuCFs)

\begin{tabular}{|lcc|}
\hline Stn & Depth (m) & $\begin{array}{c}\text { Leu to C CF } \\
\left(\mathrm{kg} \mathrm{C} \mathrm{mol}^{-1} \mathrm{Leu}\right)\end{array}$ \\
\hline T1 & 540 & 0.67 \\
T1 & 800 & 0.55 \\
T6 & 400 & 0.59 \\
T6 & 800 & 0.54 \\
T14 & 400 & 0.27 \\
T14 & 800 & 0.13 \\
T15 & 400 & 0.66 \\
T15 & 800 & 0.85 \\
\hline
\end{tabular}

towards offshore, suggesting that leucine catabolism might be related to low CFs. Thus, a proportion of the leucine taken up is not used for protein synthesis and, hence, for biomass production, but is rather respired. We suggest that similar processes as reported for oligotrophic surface waters also take place in the dark ocean, where carbon limitation and a slower prokaryotic growth than in surface waters are generally reported. The slow growth of deep-ocean prokaryotes could also involve a relatively higher protein turnover than in surface waters, further reducing the deepwater CFs as compared to the theoretical one. AlonsoSáez et al. (2007) specifically tested the possibility of protein turnover and did not find a significant influence of this process on the low CFs measured in oligotrophic surface waters, but similar measurements in the dark ocean are lacking. Overall, our results suggest a possible overestimation of carbon production (and concomitantly of PGE) in deep waters if calculated from leucine incorporation measurements using the commonly applied theoretical CF.

\section{Variability of prokaryotic growth efficiencies in the dark ocean}

The use of different approaches for estimating PHP in the incubation experiments resulted in a considerable range of deep-water PGEs (Table 3). A similar conclusion was reached by Alonso-Sáez et al. (2007) for the oligotrophic surface waters of the same study area (NE subtropical Atlantic) and by P. A. del Giorgio et al. (pers. comm.) for north Pacific waters. Using the theoretical $\mathrm{CF}\left(\mathrm{CF}_{\mathrm{t}}\right)$ and the PHP measured at the start of the incubation $\left(\mathrm{PHP}_{\mathrm{t} 0} \mathrm{CF}_{\mathrm{t}}\right)$ resulted in PGEs one order of magnitude lower (PGE ranging between $<1$ and $2 \%$ ), as compared to the integrated PHP $\left(\mathrm{PHP}_{\text {int }} \mathrm{CF}_{\mathrm{t}}\right)$, determined over the course of the incubation (PGE ranging between $<1$ and $34 \%$ ), or the average value based on the increase in prokaryotic biomass (PBM; PGE ranging between <1 and 33\%) (Table 3). Averaging all the different approaches, PGEs ranged from $<1$ to $24 \%$ (Table 3 ). The highest PGE estimates for deep waters are similar to the average PGE of surface water prokaryotes (del Giorgio \& Cole 2000) and are within the range reported by Alonso-Sáez et al. (2007) for the surface waters of the same study region (1 to $56 \%$ ). Although there are only a few reports of PGE available for the dark ocean, the ranges obtained in the present study also fall close to the PGEs measured or estimated in other studies. Arístegui et al. (2005) estimated an average PGE of $18 \pm 3 \%$ and $13 \pm 2 \%$ at $600 \mathrm{~m}$ and $1000 \mathrm{~m}$ depths, respectively, for the same study region. In an experimental simulation at the Bermuda Atlantic 
Table 3. Prokaryotic respiration (PR), biomass production (PBM) estimated from the change in abundance assuming a carbon content per cell of $12 \mathrm{fg} \mathrm{C}^{-1} \mathrm{cell}^{-1}$ (Fukuda et al. 1998), leucine-based (using theoretical CF of $1.55 \mathrm{~kg} \mathrm{C} \mathrm{mol}^{-1} \mathrm{Leu}$ ) prokaryotic heterotrophic production at the initial incubation time $\left(\mathrm{PHP}_{\mathrm{t} 0} \mathrm{CF}_{\mathrm{t}}\right)$ and integrated over $48 \mathrm{~h}$ of incubation $\left(\mathrm{PHP}_{\text {int }} \mathrm{CF}_{\mathrm{t}}\right)$, prokaryotic growth efficiency (PGE; \%) range and average (see text for details), and PGE calculated from the empirically obtained carbon-to-leucine $\left(\mathrm{PGE} \mathrm{CF}_{\mathrm{e}}\right)$. Metabolic rates are

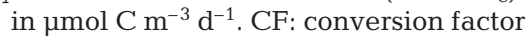

\begin{tabular}{|ccccccccc|}
\hline Stn & Depth (m) & PR & PBM & PHP $_{\text {t } 0} \mathrm{CF}_{t}$ & PHP $_{\text {int }} \mathrm{CF}_{\mathrm{t}}$ & PGE $_{\text {range }}$ & PGE $_{\text {avg }}$ & PGE CF \\
\hline R2 & 350 & 480 & 8 & $<1$ & 1 & $<1-2$ & 1 & \\
R2 & 1000 & 970 & 4 & $<1$ & 1 & $<1$ & $<1$ & \\
T1 & 540 & 1180 & 33 & 6 & 277 & $1-19$ & 7 & 9 \\
T1 & 800 & 450 & - & $<1$ & 114 & $<1-20$ & 10 & 8 \\
T2 & 400 & 1040 & 13 & 4 & 260 & $<1-20$ & 7 & \\
T2 & 800 & 120 & 22 & 2 & 38 & $2-24$ & 14 & \\
T6 & 800 & 170 & 18 & 1 & 28 & $<1-14$ & 7 & 4 \\
T9 & 400 & 590 & 13 & 8 & 70 & $1-11$ & 4 & \\
T9 & 800 & 490 & 52 & 2 & 110 & $<1-18$ & 10 & \\
T11 & 400 & 190 & 9 & 2 & 38 & $1-17$ & 7 & \\
T11 & 800 & 90 & 44 & 1 & 47 & $1-34$ & 24 & \\
T14 & 400 & 190 & 25 & 2 & 27 & $1-16$ & 8 & 3 \\
T14 & 800 & 190 & 29 & 2 & 6 & $1-13$ & 6 & $<1$ \\
\hline
\end{tabular}

Time-Series Study (BATS) site, Carlson et al. (2004) estimated PGE to be $8 \pm 4 \%$ for the upper mesopelagic prokaryotic assemblage after convective overturn. Reinthaler et al. (2006) found an average PGE of $2 \pm 1 \%$ in the meso- and bathypelagical realm of the North Atlantic Ocean. Tanaka \& Rassoulzadegan (2004), by replacing total amount of organic carbon assimilated by prokaryotes with the organic carbon flux, estimated an annual PGE of 19 to $39 \%$ for the mesopelagic layers of the northwest Mediterranean Sea. Zaccone et al. (2003) estimated a PGE range of 6 to $21 \%$ for the water column of the Ionian Sea from electron transport system (ETS) measurements, the highest PGE corresponding to the deepest water mass (2000 to $3500 \mathrm{~m}$ depth). Therefore, all of the above results (except Reinthaler et al. 2006) suggest that PGEs in the mesopelagic realm are not always as low as predicted from the empirical function proposed by del Giorgio \& Cole (1998), although there is a high variability of PGE estimates depending on the approach chosen to compute PHP (Table 3).

Based on the PGE measured, as well as on other metabolic proxies for prokaryotes, Arístegui et al. (2005) claimed that the mesopelagic prokaryotic assemblage in the subtropical NE Atlantic is as active as that of the surface waters, even though prokaryotic abundance is lower in the mesopelagic realm than in surface waters. Overall, although some uncertainties remain on the actual PGEs, deep-ocean PGEs appear to be comparable to the PGEs of oligotrophic surface waters, suggesting that dark-ocean prokaryotes can play a substantial role in the marine carbon flux.

\section{Relationship between CFs and PGE in the dark ocean}

As shown above, CF variability is high in the dark ocean, influencing the PHP and PGE estimates of deep-ocean prokaryotes (Table 3). In experiments with surface waters, decreases in empirically determined CFs along decreasing trophic gradients have been reported for the Mediterranean Sea (Pedros-Alió et al. 1999), the NE Pacific Ocean (Sherr et al. 2001) and for the NE Atlantic Ocean (Alonso-Sáez et al. 2007). These trends suggest that CFs are ecologically constrained and not just confinement artifacts caused by bottle enclosures (Massana et al. 2001). However, for deep waters this is not so clear due to the low number of $\mathrm{CF}$ experiments carried out thus far.

We found a significant correlation (Pearson $r=0.93, p=0.019, n=5$, log-log transformed) between the empirically derived CFs and the PGEs estimated using the integrated PHP and the theoretical $\mathrm{CF}$, but no significant relation with the PGE obtained with the PHP measured at the start of the incubation and with the PHP calculated from the increase in prokaryotic abundance over time. It is noteworthy that autocorrelation is not responsible for this relation because PGE was estimated with the theoretical CF. Alonso-Sáez et al. (2007) also reported a correlation (Pearson $\mathrm{r}=0.86, \mathrm{p}<0.0004, \mathrm{n}=12$, log-log transformed) between empirically determined CFs and PGEs (averaging biomass increase and leucine incorporation at the start of the incubation) for the oligotrophic surface NE Atlantic Ocean. Our findings support the idea that, also in the dark ocean, both parameters (CF and PGE) reflect basically the same physiological processes as reported for surface water prokaryotes (Alonso-Sáez et al. 2007, P. A. del Giorgio et al., pers. comm.).

Acknowledgements. This research was supported by the Spanish 'Plan Nacional de I+D' (MEC) under the RODA (CTM2004-06842-C03-03/MAR) and CAIBEX (CTM200766408-C02-02) grants to J.A., a grant of the Earth and Life Science Division of the Dutch Science Foundation (ALW-NWO; ARCHIMEDES project, 835.20.023) to G.J.H., and a predoctoral Fellowship of the Spanish Ministry of Education and Science (AP2005-3932) to F.B. Projects MODIVUS (CTM2005-04795/ MAR) and STORM (CTM2009-09352/MAR) supported J.M.G. The work was carried out within the frame of the EU 'Networks of Excellence' MarBef, and EurOceans. We thank the captain and crew of R/V 'Hespérides' for their support at sea, and M. Espino and I. Alonso-González for their help with the respiration estimates. We also thank 3 anonymous reviewers for their comments and suggestions that improved the manuscript. 


\section{LITERATURE CITED}

Alonso-Saéz L, Gasol JM, Aristegui J, Vilas JC, Vaqué D, Duarte CM, Agusti S (2007) Large-scale variability in surface bacterial carbon demand and growth efficiency in the subtropical northeast Atlantic Ocean. Limnol Oceanogr 52:533-546

Arístegui J, Duarte CM, Gasol JM, Alonso-Sáez L (2005) Active mesopelagic prokaryotes support high respiration in the subtropical northeast Atlantic Ocean. Geophys Res Lett 32:L03608, doi:03610.01029/02004GL021863

Arístegui J, Gasol JM, Duarte CM, Herndl GJ (2009) Microbial oceanography of the dark ocean's pelagic realm. Limnol Oceanogr 54:1501-1529

Azam F, Fenchel T, Field JG, Gray JS, Meyer-Reil LA, Thingstad F (1983) The ecological role of water-column microbes in the sea. Mar Ecol Prog Ser 10:257-263

Baltar F, Sintes E, Van Aken H, Gasol JM, Arístegui J, Herndl GJ (2009) Prokaryotic extracellular enzymatic activity in relation to biomass production and respiration in the meso- and bathypelagic waters of the (sub)tropical Atlantic. Environ Microbiol 11:1998-2014

Bjørnsen PK, Kuparinen J (1991) Determination of bacterioplankton biomass, net production and growth efficiency in the Southern Ocean. Mar Ecol Prog Ser 71:185-194

Carlson CA, del Giorgio PA, Herndl GJ (2007) Microbes and the dissipation of energy and respiration: from cells to ecosystems. Oceanography (Wash DC) 20:89-100

Carlson CA, Ducklow HW (1996) Growth of bacterioplankton and consumption of dissolved organic carbon in the Sargasso Sea. Aquat Microb Ecol 10:69-85

Carlson CA, Giovannoni SJ, Hansell DA, Goldberg SJ, Parsons R, Vergin K (2004) Interactions among dissolved organic carbon, microbial processes, and community structure in the mesopelagic zone of the northwestern Sargasso Sea. Limnol Oceanogr 49:1073-1083

del Giorgio PA, Williams PJleB (2005) The global significance of respiration in aquatic ecosystems: from single cells to the biosphere. In: Williams PJleB, del Giorgio PA (eds) Respiration in aquatic ecosystems. Oxford University Press, New York, NY

del Giorgio PA, Cole JJ (1998) Bacterial growth yield efficiency in natural aquatic systems. Annu Rev Ecol Syst 29: 503-541

del Giorgio PA, Cole JJ (2000) Bacterial energetics and growth efficiency. In: Kirchman DL (ed) Microbial ecology of the oceans. Wiley-Liss, New York, NY, p 289-325

del Giorgio PA, Pace ML, Fischer D (2006) Relationship of bacterial growth efficiency to spatial variation in bacterial activity in the Hudson River. Aquat Microb Ecol 45: $55-67$

Ducklow H (2000) Bacterial production and biomass in the oceans. In: Kirchman DL (ed) Microbial ecology of the oceans. Wiley-Liss, New York, NY, p 85-120

Ducklow HW, Carlson CA, Smith WO (1999) Bacterial growth in experimental plankton assemblages and seawater cultures from Phaeocystis antartica bloom in the Ross Sea. Aquat Microb Ecol 19:215-227

Editorial responsibility: Hugh Ducklow, Woods Hole, Massachusetts, USA
Fukuda R, Ogawa H, Nagata T, Koike I (1998) Direct determination of carbon and nitrogen contents of natural bacterial assemblages in marine environments. Appl Environ Microbiol 64:3352-3358

- Gasol JM, Alonso-Sáez L, Vaqué D, Baltar F, Calleja ML, Duarte CM, Arístegui J (2009) Mesopelagic prokaryotic bulk and single-cell heterotrophic and community composition in the NW Africa-Canary Islands coastal-transition zone. Prog Oceanogr 83:189-196

Ihaka R, Gentleman R (1996) R: a language for data analysis and graphics. J Comput Graph Statist 5:299-314

Kirchman DL (1992) Incorporation of thymidine and leucine in the subarctic Pacific: application to estimating bacterial production. Mar Ecol Prog Ser 82:301-309

Massana R, Pedrós-Alió C, Casamayor EO, Gasol JM (2001) Changes in marine bacterioplankton phylogenetic composition during incubations designed to measure biogeochemically significant parameters. Limnol Oceanogr 46: $1181-1188$

> Pedros-Alió C, Calderon-Paz JI, Guixa-Boixereu N, Estrada M, Gasol JM (1999) Bacterioplankton and phytoplankton biomass and production during summer stratification in the northwestern Mediterranean Sea. Deep-Sea Res I 46: 985-1019

> Pulido-Villena E, Reche I (2003) Exploring bacterioplankton growth and protein synthesis to determine conversion factors across a gradient of dissolved organic matter. Microb Ecol 46:33-42

Reinthaler T, Aken HV, Veth C, Williams PJleB, and others (2006) Prokaryotic respiration and production in the mesoand bathypelagic realm of the eastern and western North Atlantic basin. Limnol Oceanogr 51:1262-1273

Robinson C, Williams PJleB (2005) Respiration and its measurements in surface marine waters. In: Williams PJleB, del Giorgio PA (eds) Respiration in aquatic ecosystems. Oxford University Press, New York, NY

Sherr EB, Sherr BF, Cowles TJ (2001) Mesoscale variability in bacterial activity in the northeast Pacific Ocean off Oregon, USA. Aquat Microb Ecol 25:21-30

Sherry ND, Imanian B, Sugimoto K, Boyd PW, Harrison PJ (2002) Seasonal and interannual trends in heterotrophic bacterial processes between 1995 and 1999 in the subarctic NE Pacific. Deep-Sea Res II 49:5775-5791

Smith DC, Azam F (1992) A simple, economical method for measuring bacterial protein synthesis rates in seawater using ${ }^{3} \mathrm{H}$-leucine. Mar Microb Food Webs 6:107-114

> Tanaka T, Rassoulzadegan F (2004) Vertical and seasonal variations of bacterial abundance and production in the mesopelagic layer of the NW Mediterranean Sea: bottomup and top-down controls. Deep-Sea Res I 51:531-544

Zaccone R, Monticelli LS, Seritti A, Santinelli C and others (2003) Bacterial processes in the intermediate and deep layers of the Ionian Sea in winter 1999: vertical profiles and their relationship to the different water masses. J Geophys Res 108:8117-8128

Zubkov MV, Seigh MA, Burkill PH, Leakey RJG (2000) Bacterial growth and grazing loss in contrasting areas of North and South Atlantic. J Plankton Res 22:685-711

Submitted: June 30, 2009; Accepted: April 9, 2010

Proofs received from author(s): June 1, 2010 